\title{
Synthetic studies towards the development of a novel class of acitretin-type retinoids
}

\author{
George Magoulas and Dionissios Papaioannou* \\ Department of Chemistry, University of Patras, GR-26500 Patras, Greece \\ E-mail: d.a.papaioannou@chemistry.upatras.gr
}

Dedicated to Professor Anastasios Varvoglis on the occasion of his $65^{\text {th }}$ birthday

(received 03 Feb 03; accepted 28 Mar 03; published on the web 12 Sept 03)

\begin{abstract}
3,4,5-Trimethoxyaniline, indole-3-carboxylic acid and the dicarboxylic acids fumaric, maleic, succinic and phthalic have been combined to produce novel analogs of the aromatic retinoid acitretin. These analogs are characterized by a highly electron-rich benzene ring in the lipophilic part and two amide bonds, replacing the C7-C8 and C11-C12 double bonds, with simultaneous restriction of the $\mathrm{C} 9-\mathrm{C} 10$ double bond, in the spacer compared to acitretin. In addition, the terminal trans $\mathrm{C} 13-\mathrm{C} 14$ double bond has been either retained or isomerized or reduced or incorporated within an indole nucleus with simultaneous replacement of the carboxy group by the indole imine function. The related syntheses involved coupling of the $N$-Boc protected indole-3-carboxylic acid with 3,4,5-trimethoxyaniline, acid-mediated removal of the Boc group, coupling of the thus obtained anilide with the anhydrides or suitable monoesters of the above mentioned dicarboxylic acids in liquid or on solid phase and finally deprotection.
\end{abstract}

Keywords: Acitretin analogs, anilines, dicarboxylic acids, indole-3-carboxylic acid, protecting groups, retinoids

\section{Introduction}

Retinoids, a large family of natural and synthetic compounds structurally related to vitamin A (retinol, 1), play an important role in a variety of biological functions, including vision, development, reproduction and cell differentiation and have been applied successfully to the management of severe and recalcitrant skin disorders and more recently to cancer prevention and therapy. In particular, the synthetic analogs of all-trans-retinoic acid (2) 13-cis-retinoic acid (isotretinoin, 3) and acitretin (4) are presently regarded as the drugs of choice for the treatment of acne and rosacea and psoriasis, ichthyosis, Darier's disease and other keratinization disorders, respectively. However, retinoids are toxic compounds in large doses, cause skin inflammation, hyperlipidemia and severe neurological abnormalities and are teratogenic. In order to improve the therapeutic efficacy to toxicity index as well as to develop better selectivities for various 
therapeutic applications, e.g. in dermatology, oncology, reumatology, immunology etc, a huge array of analogs has been synthesized and their biological activity determined. These analogs incorporate changes in one or more of the three discrete structural parts of the parent retinoid 2, namely the lipophilic part (the polymethylated cyclohexene ring), the hydrophilic part (the carboxy function) and the spacer (the polyene chain). For example, in isotretinoin (3) the natural (trans) configuration of the 13-double bond has changed to cis, in acitretin (4) the lipophilic part has been replaced by a lipophilic/electron rich aromatic ring, in amide $\mathbf{5}$ a double bond has been replaced by its isosteric amide bond whereas in both the amide 5 and the arotinoid Ro13-7410 (6, Figure 1) conformational restrains have been introduced into the molecules in the form of aromatic rings. ${ }^{1}$
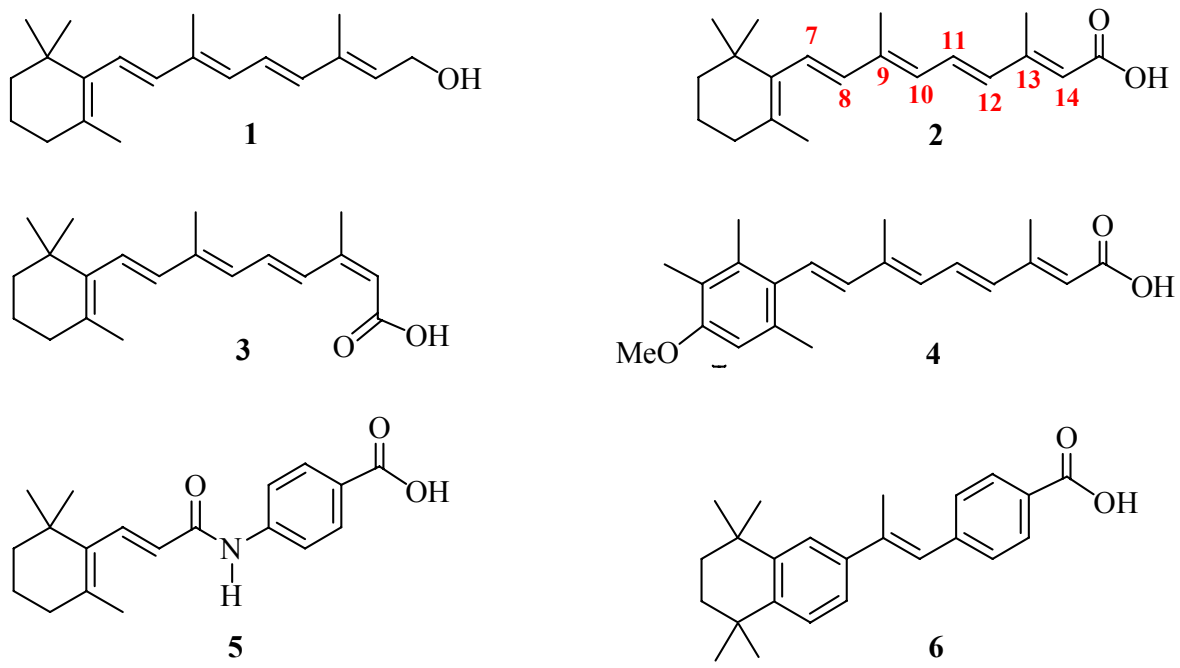

Figure 1. Structures of natural and synthetic retinoids relevant to this work.

The current practice to develop new retinoid-type drugs involves the synthesis of ligands for the nuclear receptors of retinoic acid $\operatorname{RAR} \alpha, \beta, \gamma$ and $\operatorname{RXR} \alpha, \beta, \gamma$ and the orphan receptors through which gene expression is regulated. ${ }^{2}$ Recent studies, however, have shown that natural (1 and 2) and synthetic (3 and 4 ) retinoids, currently used as antipsoriatic agents, inhibit the enzyme RNase P isolated from the slime mold Dictyostelium discoideum, the most potent inhibitor being acitretin (4). Arotinoid Ro13-7410 is also a strong inhibitor of this enzyme. These studies showed that the retinoids also regulate, most possibly through allosteric interactions with lipophilic site(s) of RNase P, the activity of enzymes playing a decisive role in the biosynthesis of macromolecules and that important structural features for stronger interactions are the hydrophilic carboxy function and the hydrophobic substituted aromatic ring, whereas the configuration of the double bond in position 13 seemed not to play an important role. ${ }^{3}$ We now wish to report on our initial synthetic efforts to develop a new class of retinoids, in which the parent structure of acitretin is changed in the following ways. One or more methoxy groups are introduced in the lipophilic part of the molecule to increase the electron density of the aromatic nucleus, two of the double bonds, namely C7-C8 and $\mathrm{C} 11-\mathrm{C} 12$, of the spacer are replaced by isosteric amide bonds whereas one of the double bonds, namely $\mathrm{C} 9-\mathrm{C} 10$, is restrained within an 
heterocyclic ring (Figure 2). The structural diversity projected for this class of acitretin analogs can be secured by a combination of (a) polymethoxylated anilines (e.g. 2,4-dimethoxy- and 3,4,5-trimethoxyaniline) to provide the lipophilic part of the molecules, (b) suitable heterocyclic amino acids (e.g. indole- or pyrrole-3-carboxylic acid) to build on the spacer and incorporate a conformational restriction (e.g. structures 7-9a) and (c) an unsaturated 1,4-dicarboxylic acid to complete the spacer and provide the carboxy group (e.g structures 7a-c). The latter could be furthermore replaced by the relatively acidic NH group of the indole nucleus (structure 7e) whereas the double bond next to the carboxy group can be replaced by an ethylene group to increase conformational freedom in this part of the molecule (structure 7d). For the purpose of the present studies we chose to use the commercially available 3,4,5-trimethoxyaniline and indole-3-carboxylic acid to build up the right half part of the molecules, whereas the other half was provided by the also commercially available fumaric, maleic, succinic and phthalic acids.<smiles>COc1cc(C)c(/C=C/C(C)=C/C=C/C(C)=C/C(=O)O)c(C)c1C</smiles><smiles>COc1ccc(N)c(OC)c1</smiles><smiles>COc1cc(NC(=O)c2ccn(C(=O)/C=C/C(=O)O)c2)cc(OC)c1OC</smiles><smiles>COc1cc(NC(=O)C2=CN(C(=O)/C=C/C(=O)O)C=CC2)cc(OC)c1OC</smiles><smiles>COc1cc(NC(=O)c2cn(C(=O)/C=C/C(=O)O)c3ccccc23)cc(OC)c1OC</smiles><smiles>COc1cc(NC(=O)c2cn(C(=O)/C=C\C(=O)O)c3ccccc23)cc(OC)c1OC</smiles><smiles>COc1cc(NC(=O)c2cn(C(=O)c3c[nH]c4ccccc34)c3ccccc23)cc(OC)c1OC</smiles><smiles>COc1cc(NC(=O)c2cn(C(=O)c3ccccc3C(=O)O)c3ccccc23)cc(OC)c1OC</smiles><smiles>COc1cc(NC(=O)c2cn(C(=O)CCC(=O)O)c3ccccc23)cc(OC)c1OC</smiles>

Figure 2. Structures of the new acitretin analogs described in this work. 


\section{Results and Discussion}

\section{Synthesis of the key-intermediate anilide 13 and the acitretin analog $7 \mathrm{a}$}

Taking into consideration that all projected synthetic targets 7a-e share as the common structural feature the anilide 13 (see Scheme 1), we decided to develop first an efficient method for the preparation of this key-intermediate. We envisaged that coupling of 3,4,5-trimethoxyaniline with a suitably $N$-protected derivative of indole-3-carboxylic acid (10), followed by deprotection, would provide an ease access to anilide 13. The imino function in pyrroles or indole and derivatives, e.g. amino acids incorporating the indole heterocycle, has been traditionally protected with the tert-butoxycarbonyl (Boc) group. This protecting group is cleanly introduced in such molecules using di-tert-butyl dicarbonate $\left(\mathrm{Boc}_{2} \mathrm{O}\right)$ in the presence of 4dimethylaminopyridine (DMAP) and $\mathrm{MeCN}$ as the solvent and can be then readily removed by trifluoroacetic acid (TFA)-mediated acidolysis. ${ }^{5}$

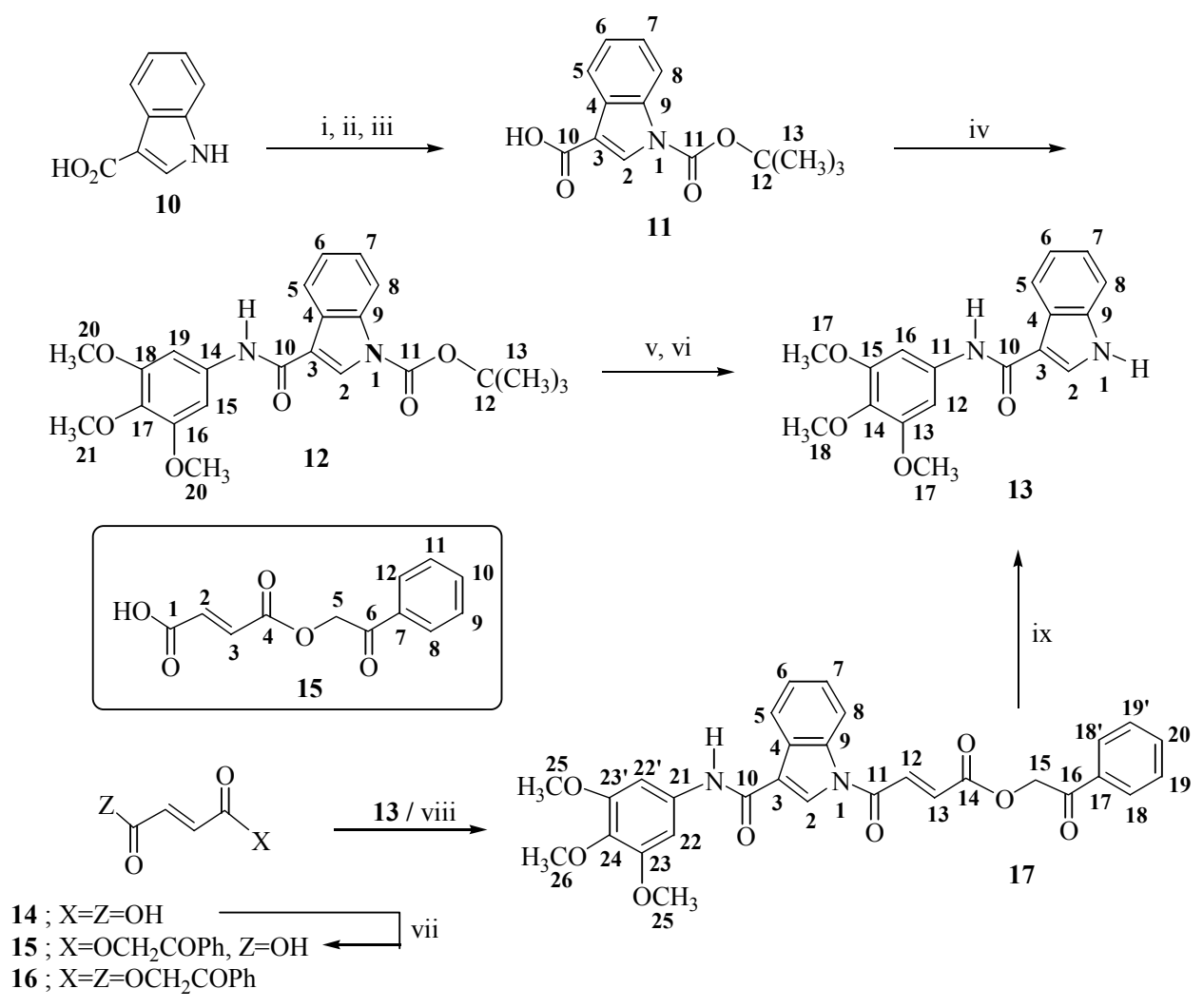

Scheme 1. Synthesis of the key-intermediate anilide 13. Reagents and conditions : (i) $\mathrm{Me}_{3} \mathrm{SiCl} /{ }^{\mathrm{i}} \mathrm{Pr}_{2} \mathrm{NEt}, \mathrm{CHCl}_{3} / \mathrm{MeCN}$ (3:2), reflux, $30 \mathrm{~min}$; (ii) Boc ${ }_{2} \mathrm{O} /$ cat. DMAP, reflux, $2.5 \mathrm{~h}$ then $25^{\circ} \mathrm{C}, 16 \mathrm{~h}$; (iii) $\mathrm{MeOH}, 60 \%$; (iv) 3,4,5-trimethoxyaniline $/ \mathrm{PyBrOP} /{ }^{\mathrm{i}} \mathrm{Pr}_{2} \mathrm{NEt}, \mathrm{CHCl}_{3}, 25^{\circ} \mathrm{C}, 16 \mathrm{~h}$, $81 \%$; (v) $\mathrm{CF}_{3} \mathrm{CO}_{2} \mathrm{H} / \mathrm{CH}_{2} \mathrm{Cl}_{2}(1: 1), 25^{\circ} \mathrm{C}, 1 \mathrm{~h}$; (vi) 5\% aqueous $\mathrm{NaHCO}_{3}, 60 \%$; (vii) $\mathrm{PhCOCH}_{2} \mathrm{Br} /{ }^{\mathrm{i}} \mathrm{Pr}_{2} \mathrm{NEt}, \mathrm{DMF}, 25^{\circ} \mathrm{C}, 16 \mathrm{~h}, 34 \%$; (viii) $\mathrm{PyBrOP} /{ }^{\mathrm{i}} \mathrm{Pr}_{2} \mathrm{NEt} /$ cat. DMAP, $\mathrm{CHCl}_{3} / \mathrm{MeCN}$ (1:1), $25^{\circ} \mathrm{C}, 5 \mathrm{~min}, 70 \%$; (ix) $\mathrm{PhSH} / \mathrm{NaH} /$ cat. imidazole, DMF, $25^{\circ} \mathrm{C}, 4 \mathrm{~h}, 85 \%$. 
We preferred to use an alternative method for the introduction of the Boc group into amino acid 10 which involved persilylation of the latter with $\mathrm{Me}_{3} \mathrm{SiCl}$ in $\mathrm{CHCl}_{3}$ and $\mathrm{MeCN}$ in the presence of $N, N$-diisopropylethylamine (DIPEA) and DMAP, followed by $\mathrm{Boc}_{2} \mathrm{O}$-mediated N-Si bond splitting and finally methanolysis of the resulting trimethylsilyl ester. ${ }^{6}$ Accordingly, the Boc-protected derivative 11 was obtained in 66\% yield. Coupling of this acid with 3,4,5trimethoxyaniline was best performed in the presence of the strong coupling agent bromotripyrrolidinophosphonium hexafluorophosphate (PyBrOP) and DIPEA in $\mathrm{CHCl}_{3}$ to give the expected anilide 12 in $81 \%$ yield. Finally, treatment of Boc-protected anilide 12 with a 50\% solution of TFA in $\mathrm{CH}_{2} \mathrm{Cl}_{2}$ for $1 \mathrm{~h}$ at ambient temperature effected its complete deprotection. From the thus obtained trifluoroacetate salt, the free anilide $\mathbf{1 3}$ was obtained in $60 \%$ yield after routine neutralization with a $5 \%$ aqueous $\mathrm{NaHCO}_{3}$ solution.

Attachment of the fumaryl unit to anilide 13 required the selective protection of one of its carboxy functions. Based on previous work of our group on the selective protection of $\alpha, \omega$ dicarboxylic acids and their use to effect intermolecular bridging of polyamine moieties, ${ }^{7}$ we decided to use the phenacyl group for this purpose. This group is readily introduced into the carboxy function, monoprotected derivatives are readily separated by flash column chromatography (FCC) from the undesired byproducts from diesterification and finally it is efficiently removed under mild reaction conditions with sodium thiophenolate. Thus, reaction of fumaric acid (14) with phenacyl bromide in DMF in the presence of DIPEA provided the anticipated monophenacyl ester 15 along with the diphenacyl ester 16. From this reaction mixture, monoester 15 was readily isolated in 34\% yield through routine FCC. Coupling of this compound with anilide 13 in $\mathrm{CHCl}_{3} / \mathrm{MeCN}(1: 1)$ in the presence of PyBrOP, DIPEA and a catalytic quantity of DMAP proceeded unexceptionally to provide the phenacyl ester $\mathbf{1 7}$ in $70 \%$ yield. However, the sodium thiophenolate-mediated attempted removal of the phenacyl group resulted instead to the removal of the fumaryl moiety, due to an unexpected cleavage of the $\mathrm{N}^{\text {ind }}$ $\mathrm{CO}$ amide bond, as evidenced by the recovery of the anilide $\mathbf{1 3}$ in $85 \%$ yield.
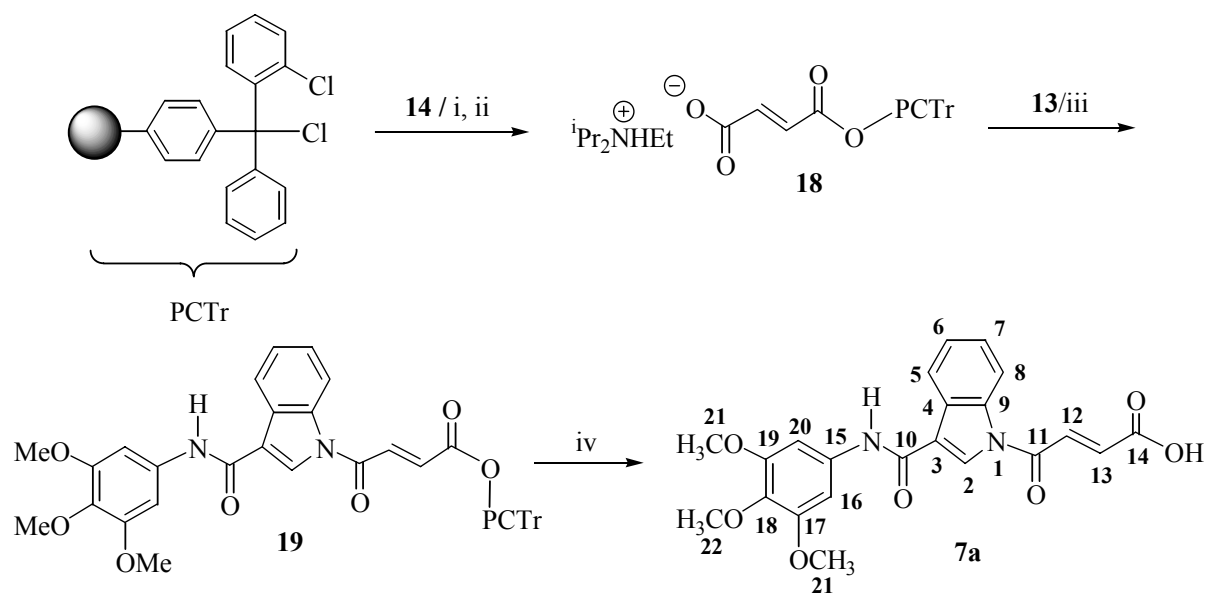

Scheme 2. Solid phase synthesis of acitretin analog 7a. Reagents and conditions : (i) ${ }^{\mathrm{i}} \mathrm{Pr}_{2} \mathrm{NEt}$, $\mathrm{DMF}, 0^{\circ} \mathrm{C}, 30 \mathrm{~min}$ then $25^{\circ} \mathrm{C}, 16 \mathrm{~h}$; (ii) $\mathrm{MeOH}, 25^{\circ} \mathrm{C}, 1 \mathrm{~h}$; (iii) $\mathrm{PyBrOP} /{ }^{\mathrm{i}} \mathrm{Pr}_{2} \mathrm{NEt}, \mathrm{CH}_{2} \mathrm{Cl}_{2} / \mathrm{DMF}$ (9:1), $25^{\circ} \mathrm{C}, 16 \mathrm{~h}$; (iv) $\mathrm{CH}_{2} \mathrm{Cl}_{2} / \mathrm{CF}_{3} \mathrm{CH}_{2} \mathrm{OH} / \mathrm{CF}_{3} \mathrm{CO}_{2} \mathrm{H}(8: 4: 1), \mathrm{CH}_{2} \mathrm{Cl}_{2}, 25^{\circ} \mathrm{C}, 1 \mathrm{~h}, 85 \%$. 
Prompted by this result we then turned our attention to carboxy protecting groups cleaved by acids and in particular of the triphenylmethyl (trityl) type, e.g. the $o$-chlorotrityl group known to be cleaved under very mild acidic conditions. In addition, we decided to use its polymeric version, namely the o-chlorotrityl resin $(\mathrm{PCTr}),{ }^{8}$ in order to further improve its selectivity towards monoesterification. Indeed, treatment of $\mathrm{PCTr}-\mathrm{Cl}$ resin $(1.5 \mathrm{meq} \mathrm{Cl} / \mathrm{g}$ resin) with fumaric acid in DMF in the presence of excess DIPEA at ambient temperature for overnight provided the polymeric monoester 18 (Scheme 2) with a calculated substitution of ca. $0.5 \mathrm{mmol}$ fumarate/g resin. Ester 18 was further reacted with the anilide 13 in $\mathrm{CH}_{2} \mathrm{Cl}_{2} / \mathrm{DMF}$ (12:1) in the presence of PyBrOP and DIPEA to give the expected polymeric bisamide 19. Finally, this resin was swallowed in $\mathrm{CH}_{2} \mathrm{Cl}_{2}$ and then treated with a solution consisted of $\mathrm{CH}_{2} \mathrm{Cl}_{2}$, trifluoroethanol (TFE) and TFA (ca. 8:4:1) for $1 \mathrm{~h}$ at ambient temperature to split off the resin the acitretin analog 7a, free of byproducts. Analog $7 \mathbf{a}$ was thus obtained in $85 \%$ overall yield based on the calculated substitution of resin 18.

\section{Reaction of anilide 13 with anhydrides en route to acitretin analogs $7 \mathrm{c}$ and $\mathrm{d}$}

We have recently developed a methodology to bridge polyamine moieties inter- or intramolecularly using as the key-step the reaction of suitably $N$-trityl protected polyamines with anhydrides of dicarboxylic acids, e.g succinic anhydride. ${ }^{7,9}$ We therefore reasoned that the acitretin analog $\mathbf{7 d}$ could be readily accessed through the reaction of anilide $\mathbf{1 3}$ with succinic anhydride. Indeed, reaction of anilide 13 with succinic anhydride in $\mathrm{CH}_{2} \mathrm{Cl}_{2}$ in the presence of $\mathrm{Et}_{3} \mathrm{~N}$ and a catalytic quantity of DMAP produced unexceptionally the acitretin analog $\mathbf{7 d}$ in $47 \%$ yield (Scheme 3). Unfortunately, attempts to apply this reaction to maleic anhydride in order to produce the acitretin analog $\mathbf{7 b}$, resembling isotretinoin, failed to produce any isolable product.

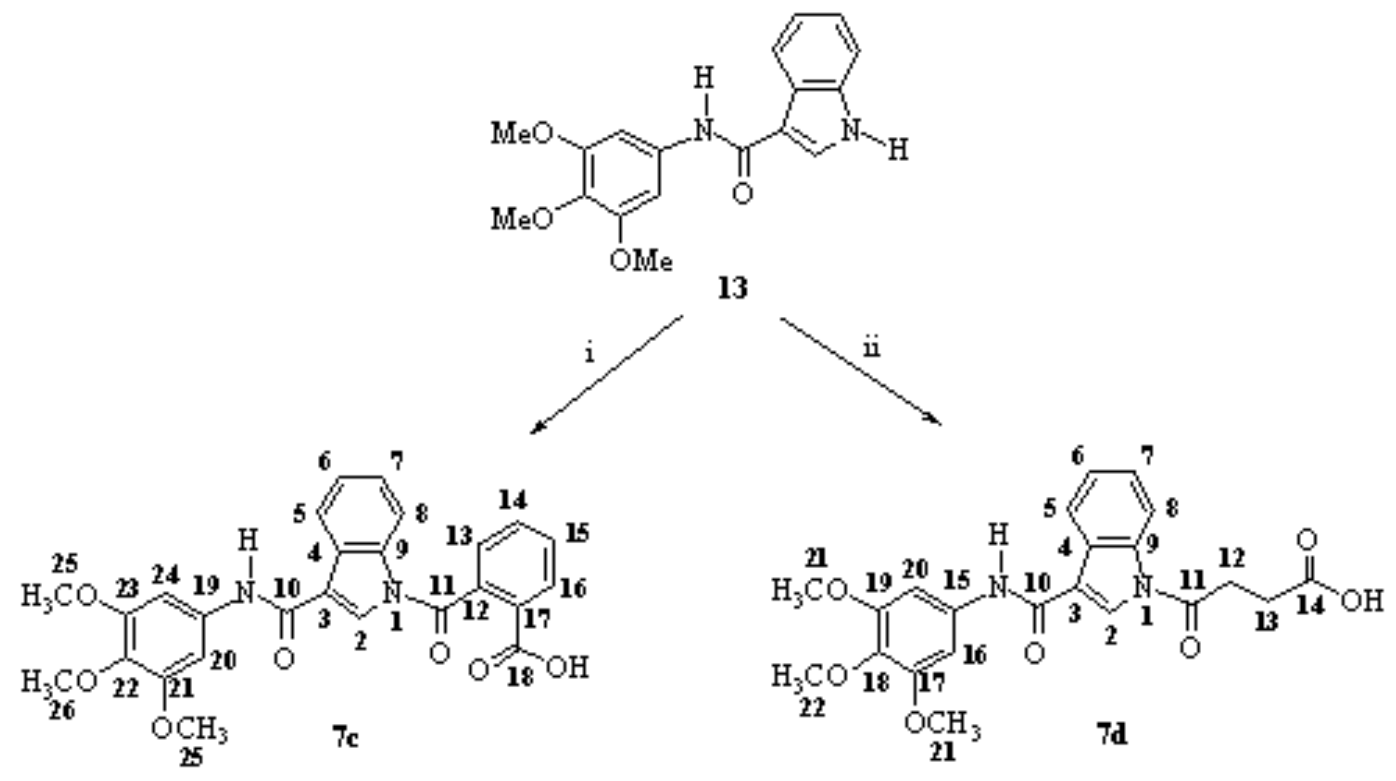

Scheme 3. Synthesis of acitretin analogs $7 \mathrm{c}$ and $\mathrm{d}$. Reagents and conditions : (i) phthalic anhydride/ ${ }^{\mathrm{i}} \mathrm{Pr}_{2} \mathrm{NEt} /$ cat. DMAP, $\mathrm{CH}_{2} \mathrm{Cl}_{2} / \mathrm{MeCN}$ (1:1), $25^{\circ} \mathrm{C}, 15 \mathrm{~min}, 84 \%$; (ii) succinic anhydride/ $\mathrm{Et}_{3} \mathrm{~N} /$ cat. DMAP, $\mathrm{CH}_{2} \mathrm{Cl}_{2}, 25^{\circ} \mathrm{C}, 1 \mathrm{~h}, 47 \%$. 
In sharp contrast was, however, the reaction of anilide 13 with phthalic anhydride. That reaction proceeded in $\mathrm{CH}_{2} \mathrm{Cl}_{2} / \mathrm{MeCN}$ (1:1), in the presence of DIPEA and a catalytic quantity of DMAP, at ambient temperature fast and smoothly and produced the anticipated acitretin analog 7c in $84 \%$ yield.

\section{Reaction of anilide 13 with monoprotected dicarboxylic or amino acids en route to the acitretin analogs $7 b$ and $e$}

Taking into consideration the fact that acitretin analog $\mathbf{7 b}$ was inaccessible through the direct reaction of anilide $\mathbf{1 3}$ with maleic anhydride, we decided to use a suitable monoester of maleic acid in order to introduce the maleyl moiety to the target molecule. We thought that the monodiphenylmethyl ester $\mathbf{2 1}$ would be a good candidate because the benzhydryl protecting group is readily removed from a carboxy function under mild acidic conditions. Indeed, reaction of benzhydrol with maleic anhydride in $\mathrm{CH}_{2} \mathrm{Cl}_{2}$ in the presence of $\mathrm{Et}_{3} \mathrm{~N}$ and a catalytic quantity of DMAP produced monoester 21 in 74\% yield (Scheme 4).<smiles>COc1cc(NC(=O)c2c[nH]c3ccccc23)cc(OC)c1OC</smiles>

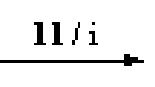

HO<smiles>CCCCOC(=O)/C=C\C(=O)O</smiles>

21
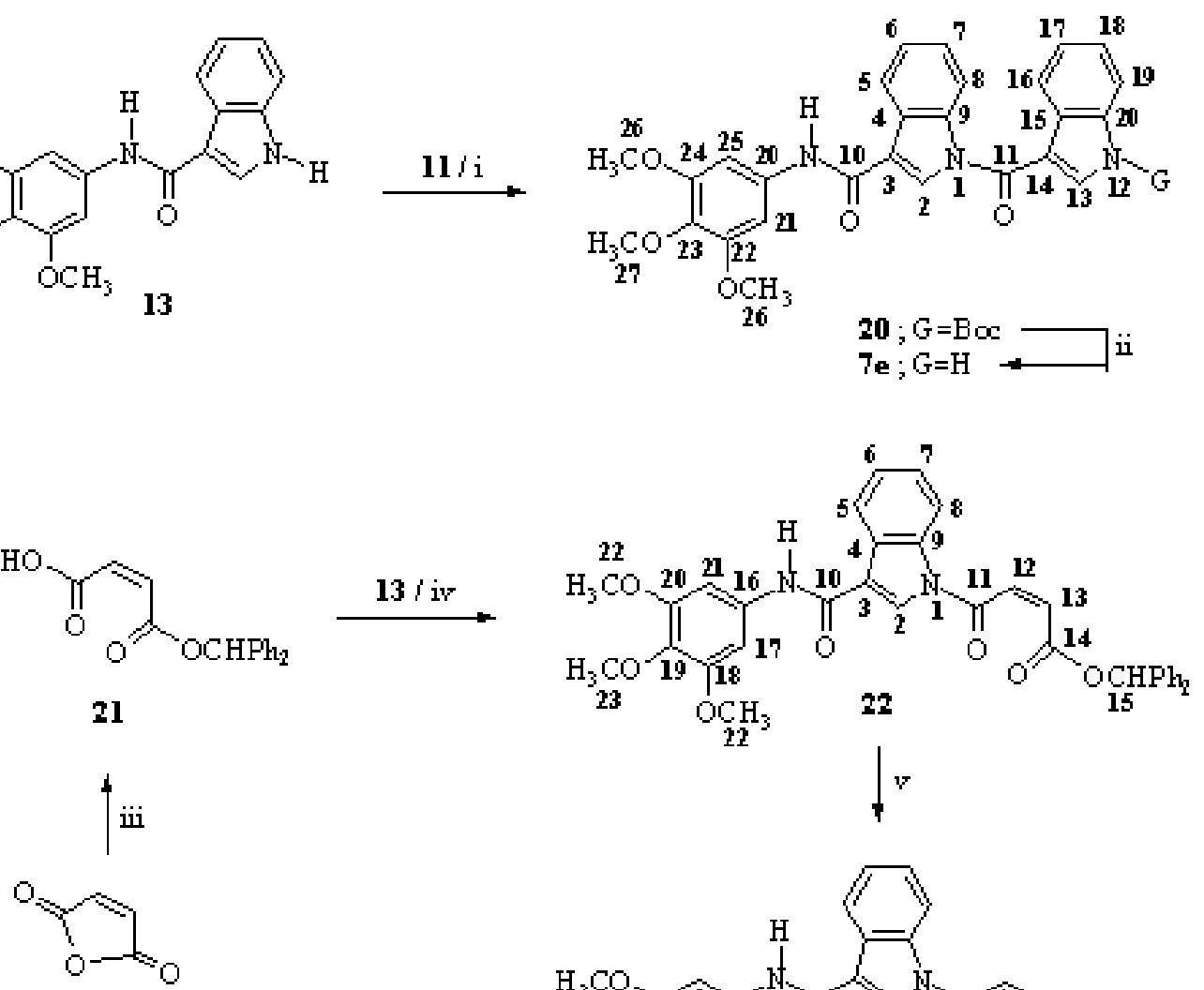<smiles>COc1cc(NC(=O)c2cn(C(=O)/C=C\C(=O)O)c3ccccc23)cc(OC)c1OC</smiles>

Scheme 4. Synthetic pathways to acitretin analogs $7 \mathrm{~b}$ and e. Reagents and conditions : (i) $\mathrm{PyBrOP} /{ }^{\mathrm{i}} \mathrm{Pr}_{2} \mathrm{NEt} /$ cat. DMAP, $\mathrm{CHCl}_{3}, 25^{\circ} \mathrm{C}, 1 \mathrm{~h}, 83 \%$; (ii) $\mathrm{CF}_{3} \mathrm{CO}_{2} \mathrm{H} / \mathrm{CH}_{2} \mathrm{Cl}_{2}(1: 1), 25^{\circ} \mathrm{C}, 1 \mathrm{~h}$, $77 \%$; (iii) $\mathrm{Ph}_{2} \mathrm{CHOH} / \mathrm{Et}_{3} \mathrm{~N} /$ cat. DMAP, $\mathrm{CH}_{2} \mathrm{Cl}_{2}, 0^{\circ} \mathrm{C}, 30$ min then $25^{\circ} \mathrm{C}, 16 \mathrm{~h}, 74 \%$; (iv) $\mathrm{PyBrOP} /$ ${ }^{\mathrm{i}} \mathrm{Pr}_{2} \mathrm{NEt} /$ cat. DMAP, $\mathrm{CH}_{2} \mathrm{Cl}_{2}, 25^{\circ} \mathrm{C}, 16 \mathrm{~h}, 56 \%$; (v) $\mathrm{CF}_{3} \mathrm{CO}_{2} \mathrm{H} \mathrm{CH}_{2} \mathrm{Cl}_{2}(1: 3), 25^{\circ} \mathrm{C}, 5 \mathrm{~min}, 60 \%$. 
Furthermore, condensation of 21 and the anilide 13 in $\mathrm{CH}_{2} \mathrm{Cl}_{2}$ in the presence of PyBrOP and $\mathrm{Et}_{3} \mathrm{~N}$ and a catalytic quantity of DMAP proceeded smoothly at ambient temperature and produced the benzhydryl ester 22 in 56\% yield. Finally, treatment of this ester with a $25 \%$ solution of TFA in $\mathrm{CH}_{2} \mathrm{Cl}_{2}$ for $5 \mathrm{~min}$ at ambient temperature produced the desired acitretin analog $7 \mathbf{b}$ in $60 \%$ yield. On the other hand, condensation of anilide 13 with the $N$-Boc protected indole-3-carboxylic acid (11) in $\mathrm{CHCl}_{3}$ in the presence of PyBrOP, DIPEA and a catalytic quantity of DMAP for I h at ambient temperature produced the intermediate $\mathbf{2 0}$ in $83 \%$ yield. This was then treated with a $50 \%$ solution of TFA in $\mathrm{CH}_{2} \mathrm{Cl}_{2}$ for $1 \mathrm{~h}$ at ambient temperature to produce the acitretin analog 7e, incorporating two adjacent indole-3-carboxylic acid units, in $77 \%$ yield.

\section{Conclusions}

The present studies have shown that novel analogs of the aromatic retinoid acitretin can be readily synthesized by using (a) commercially available compounds, such as the 3,4,5trimethoxyaniline, indole-3-carboxylic acid and the dicarboxylic acids fumaric, naleic, succinic and phthalic or their anhydrides as building blocks, (b) acid-labile, widely used, amino or carboxy protecting groups like the Boc, the diphenylmethyl and the polymeric o-chlorotrityl groups and (c) the powerful coupling agent PyBrOP to effect amide bond formation. Further applications of this methodology are currently under investigation whereas the biological evaluation of the synthesized analogs as potential RNase P inhibitors and the determination, by detailed NMR studies, of their preferred conformations in solution are now in progress.

\section{Experimental Section}

General Procedures. Melting points were determined with a Büchi SMP-20 apparatus and are uncorrected. IR spectra were recorded for $\mathrm{KBr}$ pellets on a Perkin Elmer 16PC FT-IR spectrophotometer. ${ }^{1} \mathrm{H}-\mathrm{NMR}$ spectra were obtained at $400.13 \mathrm{MHz}$ and ${ }^{13} \mathrm{C}-\mathrm{NMR}$ spectra at 100.62 $\mathrm{MHz}$ on a Bruker DPX spectrometer. $\mathrm{CDCl}_{3}$ and tetramethylsilane (TMS) were used as the solvent and internal standard, respectively, unless otherwise stated. Chemical shifts are reported in $\delta$ units, parts per million (ppm) downfield from TMS. The assignments of the ${ }^{1} \mathrm{H}$ spectra are based on chemical shift arguments, analysis of coupling patterns and signal intensities whereas the ${ }^{13} \mathrm{C}$ spectra were assigned taking into consideration chemical shift arguments. Electron-spray ionization (ESI) mass spectra were recorded on a Micromass-Platform LC spectrometer using $\mathrm{MeOH}$ or $\mathrm{MeCN}$ as solvents. Microanalyses were performed on a Carlo Erba EA 1108 CHNS elemental analyzer in the Center for Instrumental Analysis of the University of Patras.

Flash column chromatography (FCC) was performed on Merck silica gel 60 (230-400 mesh) and TLC on 60 Merck $60 \mathrm{~F}_{254}$ films $(0.2 \mathrm{~mm})$ precoated on aluminium foil. The solvent or solvent systems used for elution were: (A) $\mathrm{CHCl}_{3} / \mathrm{MeOH} /$ conc. $\mathrm{NH}_{3}$ (9:1:0.1), (B) $\mathrm{CHCl}_{3} / \mathrm{MeOH}$ 
(8:2), (C) $\mathrm{CHCl}_{3} / \mathrm{MeOH}$ (9.5:0.5), (D) EtOAc, (E) PhMe/EtOAc (1:1), (F) PhMe/EtOAc (7:3), (G) $\mathrm{PhMe} / \mathrm{EtOAc}(8: 2),(\mathrm{H}) \mathrm{CHCl}_{3} / \mathrm{MeOH} / \mathrm{gl}$. AcOH (8:2:0.5).

Spots were visualized with UV light at $254 \mathrm{~nm}$ and the charring agent $\left(\mathrm{NH}_{4}\right)_{2} \mathrm{SO}_{4}$-conc. $\mathrm{H}_{2} \mathrm{SO}_{4}-\mathrm{H}_{2} \mathrm{O}(20 \mathrm{~g}-4 \mathrm{~mL}-100 \mathrm{~mL})$. All solvents (Merck) were dried and/or purified according to standard procedures prior to use. Anhydrous $\mathrm{Na}_{2} \mathrm{SO}_{4}$ was used for drying organic solvents and subsequently solvents were routinely removed at ca. $40{ }^{\circ} \mathrm{C}$ under reduced pressure (water aspirator). All reagents employed in the present work were purchased from Aldrich and used without further purification. The o-chlorotrityl chloride resin $(\mathrm{PCTr}-\mathrm{Cl})$ was purchased from CBL Patras and had a substitution of $1.5 \mathrm{meq} \mathrm{Cl} / \mathrm{g}$ resin. With the exception of TFA-mediated deprotections, all other reactions were routinely carried out under an atmosphere of Ar. Yields of the reactions described below are not optimized.

$N$-(tert-Butoxycarbonyl)-indole-3-carboxylic acid (11). To an ice-cold $\left(0{ }^{\circ} \mathrm{C}\right)$, magnetically stirred, suspension of indole-3-carboxylic acid (6 g, $37.2 \mathrm{mmol})$ in anhydrous $\mathrm{CHCl}_{3}(55 \mathrm{~mL})$ and $\mathrm{MeCN}(37 \mathrm{~mL}) \mathrm{Me}_{3} \mathrm{SiCl}(10.4 \mathrm{~mL}, 82 \mathrm{mmol})$ and DIPEA $(14.6 \mathrm{~mL}, 84 \mathrm{mmol})$ were added sequentially. The reaction mixture was allowed to attain ambient temperature and then refluxed for $30 \mathrm{~min}$. The resulting solution allowed to attain ambient temperature, treated sequentially with DMAP (0.9 g, $7.4 \mathrm{mmol})$ and $\mathrm{Boc}_{2} \mathrm{O}(12.2 \mathrm{~g}, 55.8 \mathrm{mmol})$, then refluxed for $2.5 \mathrm{~h}$ and finally left at ambient temperature for overnight. The thus obtained reaction mixture was treated with $\mathrm{MeOH}(10 \mathrm{~mL})$ and then evaporated to dryness. The residue was treated with $100 \mathrm{~mL}$ of $5 \%$ aqueous citric acid and extracted twice with $80 \mathrm{~mL}$ of ethyl acetate (EtOAc). The organic layers were combined and sequentially washed twice with $\mathrm{H}_{2} \mathrm{O}$ and once with saturated aqueous $\mathrm{NaCl}$ (brine). The organic phase was dried and evaporated to dryness. The crude product was crystallized from EtOAc to give $3.86 \mathrm{~g}$ of pure acid 11. An additional quantity $(2.54 \mathrm{~g})$ of pure acid 11 is obtained on concentrating the mother liquid to dryness and subjecting the residue to FCC using the solvent system $\mathrm{C}$ as elunat raising the yield to $66 \%$. Acid 11 had m.p. $240-41{ }^{\circ} \mathrm{C}$, $\mathrm{R}_{\mathrm{f}}$ (C) 0.36. Anal. Calcd for $\mathrm{C}_{14} \mathrm{H}_{15} \mathrm{NO}_{4}$ (261.28): C, 64.36; H, 5.79; N, 5.36. Found: C, 64.47; $\mathrm{H}, 5.45$, N, 5.20. IR: 3200-2400 (OH), $1751(\mathrm{~N}-\mathrm{CO}-\mathrm{O}), 1684(\mathrm{CO}-\mathrm{OH}) \mathrm{cm}^{-1}$. ESI-MS $(\mathrm{m} / \mathrm{z})$ : $284.39(\mathrm{MNa}), 262.28(\mathrm{MH}) .{ }^{1} \mathrm{H}$ NMR: $\delta 8.428(1 \mathrm{H}, \mathrm{s}, \mathrm{H}-2), 8.258$ and $8.242(2 \mathrm{H}$, two dd, $J$ 6.62 and $1.83 \mathrm{~Hz}, \mathrm{H}-5$ and H-8), 7.441 and $7.414(2 \mathrm{H}$, two td, $J 7.31$ and $1.53 \mathrm{~Hz}, \mathrm{H}-6$ and $\mathrm{H}-7)$, 1.748 (9H, s, H-13) ppm. ${ }^{13} \mathrm{C}$ NMR: $\delta 169.84$ (C-10), 149.27 (C-11), 136.07 (C-9), 133.78 (C-2), 127.94 (C-3), 125.65 (C-5), 124.52 (C-8), 122.16 (C-6), 115.62 (C-7), 112.17 (C-4), 85.69 (C12) 28.50 (C-13) ppm.

$N$-(tert-Butoxycarbonyl)-3',4',5'-trimethoxy-indole-3-carboxanilide (12). To a magnetic-ally stirred solution of acid $\mathbf{1 1}(3.6 \mathrm{~g}, 13.8 \mathrm{mmol})$ and 3,4,5-trimethoxyaniline $(2.52 \mathrm{~g}$, $13.8 \mathrm{mmol})$ in dry $\mathrm{CHCl}_{3}(20 \mathrm{~mL})$ anhydrous DIPEA $(9.6 \mathrm{~mL}, 55.2 \mathrm{mmol})$ and PyBrOP $(9.78 \mathrm{~g}$, $21 \mathrm{mmol}$ ) were added sequentially. The thus obtained dark colored solution was kept at ambient temperature for overnight, then diluted with $\mathrm{CHCl}_{3}$ and finally washed sequentially once with a $5 \%$ aqueous $\mathrm{NaHCO}_{3}$ solution, twice with $\mathrm{H}_{2} \mathrm{O}$ and brine. Drying and evaporation to dryness left a residue, from which pure amide $\mathbf{1 2}(4.77 \mathrm{~g}, 81 \%$ yield) was obtained through FCC using solvent system $\mathrm{F}$ as eluant. Amide 12 had m.p. $165-66{ }^{\circ} \mathrm{C}, \mathrm{R}_{\mathrm{f}}(\mathrm{F})$ 0.43. Anal. Calcd for $\mathrm{C}_{23} \mathrm{H}_{26} \mathrm{~N}_{2} \mathrm{O}_{6}$ (426.47): C, 64.78; H, 6.15; N, 6.57. Found: C, 64.50; H, 6.46, N, 6.71. 
IR: 3300 (NH-CO), 1737 (N-CO-O), $1636(\mathrm{NH}-\mathrm{CO}) \mathrm{cm}^{-1}$. ESI-MS (m/z): $875.50(2 \mathrm{M}+\mathrm{Na})$, $449.18(\mathrm{MNa}), 427.12(\mathrm{MH}) .{ }^{1} \mathrm{H}$ NMR: $\delta 8.191(1 \mathrm{H}, \mathrm{d}, J=8.40 \mathrm{~Hz}, \mathrm{H}-8), 8.180(1 \mathrm{H}, \mathrm{s}, \mathrm{H}-2)$, $8.115(1 \mathrm{H}, \mathrm{d}, J=7.6 \mathrm{~Hz}, \mathrm{H}-5), 7.710(1 \mathrm{H}, \mathrm{s}, \mathrm{NH}), 7.412(1 \mathrm{H}, \mathrm{t}, J=7.2 \mathrm{~Hz}, \mathrm{H}-7), 7.371(1 \mathrm{H}, \mathrm{t}, J$ = 7.2 Hz, H-6), 6.971 (2H, s, H-15 and H-19), $3.886(6 \mathrm{H}, \mathrm{s}, \mathrm{H}-20), 3.842$ (3H, s, H-21), 1.701 (9H, s, H-13) ppm. ${ }^{13} \mathrm{C}$ NMR: $\delta 162.52$ (C-10), 153.88 (C-11), 149.51 (C-16 and C-18), 136.03 (C-17), 134.35 (C-14 and C-2), 128.19 (C-9), 127.69 (C-3), 125.79 (C-5), 124.36 (C-8), 121.25 (C-6), 116.86 (C-4), 115.88 (C-7), 98.53 (C-15 and C-19), 85.61 (C-12), 61.35 (C-21), 56.62 (C20), 28.52 (C-13) ppm.

3',4',5'-Trimethoxy-indole-3-carboxanilide (13). A solution of the amide 12 (2.86 g, 6.7 $\mathrm{mmol})$ in $\mathrm{CH}_{2} \mathrm{Cl}_{2}(10 \mathrm{~mL})$ and TFA $(10 \mathrm{~mL})$ was kept at ambient temperature for $1 \mathrm{~h}$ and then evaporated to dryness. Addition of $\mathrm{Et}_{2} \mathrm{O}$ and overnight refrigeration gave a precipitate, which upon filtration, washing with more $\mathrm{Et}_{2} \mathrm{O}$ and drying gave anilide $\mathbf{1 3}$ as its trifluoroacetate salt. This was then added to an excess of a $5 \%$ aqueous $\mathrm{NaHCO}_{3}$ solution and extracted twice with EtOAc. The organic layers were combined and washed twice with $\mathrm{H}_{2} \mathrm{O}$, dried and evaporated to leave a residue. Addition of $\mathrm{Et}_{2} \mathrm{O}$ and overnight refrigeration gave pure free anilide $\mathbf{1 2}$ (1.32 g, $60 \%$ ).

Anilide 13 had m.p. 201-02 ${ }^{\circ} \mathrm{C}, \mathrm{R}_{\mathrm{f}}(\mathrm{A})$ 0.33. Anal. Calcd for $\mathrm{C}_{18} \mathrm{H}_{18} \mathrm{~N}_{2} \mathrm{O}_{4}$ (326.36): C, 66.25; H, 5.56; N, 8.59. Found: C, 66.17; H5.60, N, 8.79.

IR: $3339(\mathrm{NH}-\mathrm{CO}), 3170(\mathrm{NH}), 1646(\mathrm{NH}-\mathrm{CO}) \mathrm{cm}^{-1}$. ESI-MS (m/z): $675.35(2 \mathrm{M}+\mathrm{Na})$, $349.28(\mathrm{MNa}), 327.32(\mathrm{MH}) .{ }^{1} \mathrm{H}$ NMR: $\delta 10.962(1 \mathrm{H}$, br. s, NH), $9.002(1 \mathrm{H}, \mathrm{s}, \mathrm{NHCO}), 8.261$ (1H, m, H-8), 8.070 (1H, d, J $2.92 \mathrm{~Hz}, \mathrm{H}-2), 7.453(1 \mathrm{H}, \mathrm{m}, \mathrm{H}-5), 7.236$ (2H, m, H-6 and H-7), $7.173\left(2 \mathrm{H}, \mathrm{s}, \mathrm{H}-12\right.$ and H-16) ppm. ${ }^{13} \mathrm{C}$ NMR: $\delta 166.52$ (C-10), 153.35 (C-13 and C-15), 135.99 (C-11), 134.01 (C-2), 128.70 (C-3), 126.34 (C-4), 122.81 (C-9), 121.46 (C-6), 121.37 (C-7), 112.29 (C-5), 111.87 (C-8), 98.17 (C-12 and C-16), 61.15 (C-18), 56.31 (C-17) ppm.

Fumaric acid monophenacyl ester (15). To a magnetically stirred solution of fumaric acid (14) (4.64 g, $40 \mathrm{mmol}$ ) and DIPEA ( $8 \mathrm{~mL}, 44 \mathrm{mmol}$ ) in anhydrous DMF (40 mL) phenacyl bromide (7.96 g, $40 \mathrm{mmol}$ ) was added in small portions within $1 \mathrm{~h}$ at ambient temperature. Stirring was continued overnight and then the resulting reaction mixture was diluted with EtOAc. Following filtration, the organic phase was washed sequentially twice with a 5\% aqueous citric acid solution, $\mathrm{H}_{2} \mathrm{O}$ and brine and dried. Evaporation of the solvent left a residue which was crystallized with EtOAc to give $3.18 \mathrm{~g}$ (34\% yield) of pure product. Monoester 15 had m.p. 154$55{ }^{\circ} \mathrm{C}, \mathrm{R}_{\mathrm{f}}$ (D) : 0.2. Anal. Calcd for $\mathrm{C}_{12} \mathrm{H}_{10} \mathrm{O}_{5}$ (234.21): C, 61.54; H, 4.30. Found: C, 61.42; H, 4.47.

IR: 3260-2500 (CO-OH), 1734 (CO-O), $1710(\mathrm{Ph}-\mathrm{CO}) \mathrm{cm}^{-1} .{ }^{1} \mathrm{H}$ NMR (DMSO-d 6 ): $\delta 8.006$ $(2 \mathrm{H}, \mathrm{d}, J 7.51 \mathrm{~Hz}, \mathrm{H}-8$ and H-12), $7.729(1 \mathrm{H}, \mathrm{t}, J 7.35 \mathrm{~Hz}, \mathrm{H}-10), 7.598$ (2H, t, J 7.60 Hz, H-9 and H-11), 6.869 (1H, d, J $15.7 \mathrm{~Hz}, \mathrm{H}-2), 6.616(1 \mathrm{H}, \mathrm{d}, J 15.7 \mathrm{~Hz}, \mathrm{H}-3), 5.639$ (2H, s, H-5) ppm. ${ }^{13}$ C NMR: $\delta 193.34$ (C-6), 167.54 (C-4), 165.84 (C-1), 141.77 (C-7), 134.87 (C-2), 134.68 (C-3), 129.80 (C-8 and C-2), 128.74 (C-10), 128.66 (C-9 and C-11), 67.82 (C-5) ppm.

$\mathrm{N}$-(O-Phenacylfumaryl)-3', $\mathbf{4}^{\prime}, \mathbf{5}^{\prime}$-trimethoxy-indole-3-carboxanilide $\quad$ (17). To a magneti-cally stirred solution of anilide $13(0.66 \mathrm{~g}, 2 \mathrm{mmol})$, fumaric acid derivative 15 (0.46 g, $2 \mathrm{mmol})$, a catalytic quantity of DMAP $(2.5 \mathrm{mg}, 0.02 \mathrm{mmol})$ and DIPEA (1 mL, $6 \mathrm{mmol})$ in anhydrous $\mathrm{CHCl}_{3}(2 \mathrm{~mL})$ and $\mathrm{MeCN}(2 \mathrm{~mL}) \mathrm{PyBrOP}(1.16 \mathrm{~g}, 2.5 \mathrm{mmol})$ was added. From the resulting solution a yellow precipitate is formed after $5 \mathrm{~min}$ at ambient temperature. The yellow 
precipitate, namely pure product 17 , is obtained by filtration and washing with cold $\mathrm{CHCl}_{3}$. The filtrate was washed sequentially once with a $5 \%$ aqueous $\mathrm{NaHCO}_{3}$ solution and twice with $\mathrm{H}_{2} \mathrm{O}$, dried and evaporated to leave a residue. From this residue a further quantity of product $\mathbf{1 7}$ is obtained through FCC using a s eluant the solvent system E. Totally $0.76 \mathrm{~g}$ (70\% yield) of product 17 were obtained which had $\mathrm{R}_{\mathrm{f}}(\mathrm{E}) 0.51$ Anal. Calcd for $\mathrm{C}_{30} \mathrm{H}_{26} \mathrm{~N}_{2} \mathrm{O}_{8}$ (542.55): $\mathrm{C}, 66.41$; H, 4.83; N, 5.16. Found: C, 66,75; H, 4.62; N, 4.93. ESI-MS (m/z): $565.46(M \mathrm{Na}), 543.52(M \mathrm{H})$. ${ }^{1} \mathrm{H}$ NMR (DMSO-d $\left.)_{6}\right): \delta 10.160(1 \mathrm{H}, \mathrm{s}, \mathrm{NH}), 9.023(1 \mathrm{H}, \mathrm{s}, \mathrm{H}-2), 8.533(1 \mathrm{H}, \mathrm{d}, J 7.8 \mathrm{~Hz}, \mathrm{H}-8)$, $8.378(1 \mathrm{H}, \mathrm{d}, J 6.96 \mathrm{~Hz}, \mathrm{H}-5), 8.094(3 \mathrm{H}$, two d, $J 7.67 \mathrm{~Hz}, \mathrm{H}-18$ and H-18' and $J 15.09 \mathrm{~Hz}, \mathrm{H}-$ 12), 7.769 (1H, t, J 7.4 Hz, H-20), 7.665 (2H, t, J 7.64 Hz, H-19 and H-19'), 7.541 and 7.498 $(2 \mathrm{H}$, two t, $J 6.56 \mathrm{~Hz}, \mathrm{H}-6$ and H-7), $7.296(1 \mathrm{H}, \mathrm{d}, J 15.28 \mathrm{~Hz}, \mathrm{H}-13), 7.235$ (2H, s, H-22 and H22'), 5.835 (2H, s, H-15), 3.869 (6H, s, H-25), 3.719 (3H, s, H-26) ppm. ${ }^{13} \mathrm{C}$ NMR: $\delta 192.96$ (C16), 164.95, 163.76 and 162.51 (C-10/C-11/C-14), 153.59 (C-23 and C-23'), 136.19-116.74 (aromatic and vinylic carbons), 98.71 (C-6 and C-7), 68.47 (C-15), 67.88 (C-25), 56.69 (C-26) ppm.

Attempted dephenacylation of 17-recovery of anilide (13). To an ice-cold $\left(0{ }^{\circ} \mathrm{C}\right)$ magnetically stirred suspension of $\mathrm{NaH}(30 \mathrm{mg}, 0.75 \mathrm{mmol})$ in anhydrous DMF thiophenol $(0.08$ $\mathrm{ml}, 0.75 \mathrm{mmol}$ ) and a catalytic quantity of imidazole were added. Following complete dissolution of $\mathrm{NaH}$, the bisamide $17(0.27 \mathrm{~g}, 0.5 \mathrm{mmol})$ was added and the resulting solution was allowed to attain ambient temperature where it left to stand for $4 \mathrm{~h}$. It was then diluted with an ice-cold 5\% aqueous solution citric acid, extracted twice with EtOAc and the organic layers were combined washed twice with $\mathrm{H}_{2} \mathrm{O}$, dried and evaporated to give an oily residue. From this, 0.14 $\mathrm{g}$ ( $85 \%$ yield) of anilide 13 was obtained through FCC using as eluant the solvent system E.

Polymeric $\mathbf{N}, \boldsymbol{N}$-diisopropylethylammonium salt of fumaric acid mono-o-chlorotrityl ester (18). PCTr-Cl resin (2.0130 g, $3.02 \mathrm{meq} \mathrm{Cl})$ was swallowed with DMF (10 mL), ice-cooled (0 $\left.{ }^{\circ} \mathrm{C}\right)$ and treated sequentially with DIPEA $(2.8 \mathrm{~mL}, 16 \mathrm{mmol})$ and fumaric acid (14) $(0.70 \mathrm{~g}, 6$ $\mathrm{mmol})$. The resulting reaction mixture was shaken at that temperature for $30 \mathrm{~min}$ and then for overnight at ambient temperature. $\mathrm{MeOH}(1 \mathrm{~mL})$ was then introduced into the reaction mixture, shaking was continued for a further $1 \mathrm{~h}$ and then filtered. Resin was then washed on the filter sequentially twice with $\mathrm{DMF}, \mathrm{MeOH}, \mathrm{CH}_{2} \mathrm{Cl}_{2}$ and again twice $\mathrm{DMF}, \mathrm{MeOH}$ and finally $\mathrm{Et}_{2} \mathrm{O}$. Drying overnight under high vacuum gave resin $18(2.2118 \mathrm{~g})$ with a calcd substitution of 0.476 $\mathrm{mmol} / \mathrm{g}$ resin. IR : $1720(\mathrm{CO}-\mathrm{O}), 1644(\mathrm{C}=\mathrm{C}) \mathrm{cm}^{-1}$.

Polymeric $N$-[O-(o-chloro)tritylfumaryl $]-3^{\prime}, 4^{\prime}, 5^{\prime}$-trimethoxy-indole-3-carboxanilide (19). To resin 18 (1.4834 g, $0.706 \mathrm{mmol})$, swallowed with $\mathrm{CH}_{2} \mathrm{Cl}_{2}(8.5 \mathrm{~mL})$, was added sequentially DIPEA (0.6.mL, $3.5 \mathrm{mmol})$, the anilide $13(0.57 \mathrm{~g}, 1.75 \mathrm{mmol})$ and DMF $(0.7 \mathrm{~mL})$ and finally PyBrOP $(0.82 \mathrm{~g}, 1.75 \mathrm{mmol})$. The resulting reaction mixture was shaken overnight and then the resin was filtered off and washed on the filter sequentially twice with $\mathrm{DMF}, \mathrm{MeOH}, \mathrm{CH}_{2} \mathrm{Cl}_{2}$ and again twice with $\mathrm{DMF}$ and $\mathrm{MeOH}$ and finally $\mathrm{Et}_{2} \mathrm{O}$. Drying under high vacuum for overnight gave $1.626 \mathrm{~g}$ of resin 19. IR : 1736 (CO-O), $1706(C O-\mathrm{N}), 1654\left(\mathrm{C}=\mathrm{C}\right.$ and CO-NH) cm ${ }^{-1}$.

$\mathbf{N}$-Fumaryl-3', $\mathbf{4}^{\prime}, \mathbf{5}^{\prime}$-trimethoxy-indole-3-carboxanilide (7a). Resin $19\left(\begin{array}{llll}1.6260 & \mathrm{~g}\end{array}\right)$ was swallowed with $\mathrm{CH}_{2} \mathrm{Cl}_{2}(8 \mathrm{~mL})$ and then shaken with a solution made-up of $\mathrm{CH}_{2} \mathrm{Cl}_{2}(10.75 \mathrm{~mL})$, TFE $(5 \mathrm{~mL})$ and TFA $(1.25 \mathrm{~mL})$ for $1 \mathrm{~h}$ at ambient temperature. The resin was then filtered and washed on the filter sequentially twice with a solution made-up of $\mathrm{CH}_{2} \mathrm{Cl}_{2}$ (16 mL) and TFE (4 $\mathrm{mL})$ and DMF (2 x $10 \mathrm{~mL})$. Volatile solvents were removed under reduced pressure and the 
residual DMF solution was refrigerated overnight to afford a yellow precipitate. The precipitate was discarded by filtration and the filtrate was diluted with EtOAC and washed twice with $\mathrm{H}_{2} \mathrm{O}$ and once with brine. Drying and evaporation gave $0.17 \mathrm{~g}(85 \%$ overall yield based on the calcd substitution of resin 18) of pure product 7a. Acid 7a had m.p. 253-54 ${ }^{\circ} \mathrm{C}, \mathrm{R}_{\mathrm{f}}(\mathrm{B}) 0.14$. Anal. Calcd for $\mathrm{C}_{22} \mathrm{H}_{20} \mathrm{~N}_{2} \mathrm{O}_{7}$ (424.41): C, 62.26; H, 4.75; N, 6.60. Found: C, 61.95; H, 4.83; N, 6.79.

IR: $3349(\mathrm{NH}-\mathrm{CO}), 3200-2400(\mathrm{CO}-\mathrm{OH}), 1710(\mathrm{~N}-\mathrm{CO}$ and $\mathrm{CO}-\mathrm{OH}), 1650(\mathrm{C}=\mathrm{C}), 1615$ $(\mathrm{NH}-\mathrm{CO}) \mathrm{cm}^{-1}$. ESI-MS (m/z): $463.07(\mathrm{MK}), 447.06(\mathrm{MNa}), 425.07(\mathrm{MH}) .{ }^{1} \mathrm{H}$ NMR: $\delta 11.707$ $(1 \mathrm{H}, \mathrm{s}, \mathrm{OH}), 10.056(1 \mathrm{H}, \mathrm{s}, \mathrm{NH}), 8.922(1 \mathrm{H}, \mathrm{s}, \mathrm{H}-2), 8.415(1 \mathrm{H}, \mathrm{d}, J 7.60 \mathrm{~Hz}, \mathrm{H}-8), 8.281$ (1H, d, $J 7.60 \mathrm{~Hz}, \mathrm{H}-5), 7.835$ (1H, d, J $15.20 \mathrm{~Hz}, \mathrm{H}-12), 7.431$ (1H, t, J 7.20 Hz, H-7), 7.392 (1H, t, J $7.20 \mathrm{~Hz}, \mathrm{H}-6), 7.144$ (2H, s, H-16 and H-20), 6.986 (1H, d, J $15.20 \mathrm{~Hz}, \mathrm{H}-13), 3.786$ (6H, s, H21), 3.631 (3H, s, H-22) ppm. ${ }^{13} \mathrm{C}$ NMR: $\delta 166.75,164.14$ and 162.42 (C-10/C-11/C-14), 153.61 (C-17 and C-19), 136.86-117.03 (12 C, aromatic and vinylic carbons), 98.76 (C-6 and C-7) 61.01 (C-22), 56.70 (C-21) ppm

$N$-Phthalyl-3',4',5'-trimethoxy-indole-3-carboxanilide (7c). To a magnetically stirred solution of anilide $13(0.26 \mathrm{~g}, 0.80 \mathrm{mmol})$, DIPEA $(0.18 \mathrm{~mL}, 1 \mathrm{mmol})$ and DMAP (12 $\mathrm{mg}, 0.1$ $\mathrm{mmol})$ in anhydrous $\mathrm{CH}_{2} \mathrm{Cl}_{2}(0.8 \mathrm{~mL})$ and $\mathrm{MeCN}(0.8 \mathrm{~mL})$ phthalic anhydride $(0.14 \mathrm{~g}, 0.88$ mmol) was added. After $15 \mathrm{~min}$ at ambient temperature the reaction mixture was diluted with $\mathrm{CHCl}_{3}$ and washed once with an ice-cold 5\% aqueous citric acid solution and twice with $\mathrm{H}_{2} \mathrm{O}$. Drying and evaporation to dryness left a residue from which $0.32 \mathrm{~g}$ (84\% yield) pure product 7c was obtained as a white powder through FCC using the solvent system A, pooling the fractions containing the product, washing them with 5\% aqueous citric acid solution and $\mathrm{H}_{2} \mathrm{O}$ and finally drying, evaporation and trituration with $\mathrm{Et}_{2} \mathrm{O}$. Product 7c had m.p. 200-01 ${ }^{\circ} \mathrm{C}, \mathrm{R}_{\mathrm{f}}(\mathrm{A})$ 0.11. Anal. Calcd for $\mathrm{C}_{26} \mathrm{H}_{22} \mathrm{~N}_{2} \mathrm{O}_{7}$ (474.47): C, 65.82; H, 4.67; N, 5.90. Found: C, 65.52; H, 4.93; N, 6.08.

IR: 3342 (NH-CO), 3200-2400 (OH), 1639 (CO), $1606(\mathrm{Ar} \mathrm{C}=\mathrm{C}) \mathrm{cm}^{-1}$. ESI-MS (m/z): $971.58(2 \mathrm{M}+\mathrm{Na}), 497.31(\mathrm{MNa}), 475.38(\mathrm{MH}) .{ }^{1} \mathrm{H} \mathrm{NMR}: \delta 10.407(1 \mathrm{H}, \mathrm{s}, \mathrm{OH}), 8.379(1 \mathrm{H}, \mathrm{s}$, NH), 8.146 (1H, d, J 7.28 Hz, H-8), 7.909 (1H, s, H-2), 7.752 (1H, d, J 7.41 Hz, H-5), 7.562 (1H, d, J 7.29 Hz, H-16), 7.381 (3H, m, H-13, H-14 and H-15), 7.216 (1H, t, J 7.23 Hz, H-7), $7.183(1 \mathrm{H}, \mathrm{t}, J 6.88 \mathrm{~Hz}, \mathrm{H}-6), 7.064(2 \mathrm{H}, \mathrm{s}, \mathrm{H}-20$ and H-24), 3.808 (6H, s, H-25), 3.793 (3H, s, H-26) ppm.

$\mathrm{N}$-Succinyl-3',4',5'-trimethoxy-indole-3-carboxanilide (7d). To a magnetically stirred solution of anilide $13(0.2 \mathrm{~g}, 0.6 \mathrm{mmol}), \mathrm{Et}_{3} \mathrm{~N}(0.09 \mathrm{~mL}, 0.66 \mathrm{mmol})$ and a catalytic quantity of DMAP in anhydrous $\mathrm{CH}_{2} \mathrm{Cl}_{2}(1.5 \mathrm{~mL})$ succinic anhydride $(0.07 . \mathrm{g}, 0.66 \mathrm{mmol})$ was added. After $1 \mathrm{~h}$ at ambient temperature the reaction mixture was diluted with $\mathrm{CH}_{2} \mathrm{Cl}_{2}$ and washed with an ice-cold $5 \%$ aqueous citric acid solution. The resulting white precipitate was filtered and washed on the filter sequentially twice with $\mathrm{H}_{2} \mathrm{O}, \mathrm{MeOH}$ and $\mathrm{Et}_{2} \mathrm{O}$ and dried under vacuum to give $0.12 \mathrm{~g}$ (47\%) of pure product 7d. Product 7d had m.p 202-03 ${ }^{0} \mathrm{C}, \mathrm{R}_{\mathrm{f}}$ (B) 0.24. Anal. Calcd for $\mathrm{C}_{22} \mathrm{H}_{22} \mathrm{~N}_{2} \mathrm{O}_{7}$ (426.43): C, 61.97; H, 5.20; N, 6.57. Found: C, 61.77; H, 5.31; N, 6.77.

IR: 3280 (NH-CO), 3200-2400 (CO-OH), 1740 (N-CO), $1648(\mathrm{CO}-\mathrm{OH}) \mathrm{cm}^{-1}$. ESI-MS (m/z): $876.71(2 \mathrm{M}+\mathrm{Na}), 853.67(2 \mathrm{M}+\mathrm{H}), 449.43(\mathrm{MNa}), 427.42(\mathrm{MH}) .{ }^{1} \mathrm{H}$ NMR $\left(\mathrm{DMSO}_{6}\right): \delta 12.367$ (1H, br. S, OH), 10.009 (1H, s, NH), $8.838(1 \mathrm{H}, \mathrm{s}, \mathrm{H}-2), 8.350(1 \mathrm{H}, \mathrm{d}, J 8.00 \mathrm{~Hz}, \mathrm{H}-8), 8.183$ $(1 \mathrm{H}, \mathrm{d}, J 7.60 \mathrm{~Hz}, \mathrm{H}-5), 7.392(1 \mathrm{H}, \mathrm{t}, J 7.20 \mathrm{~Hz}, \mathrm{H}-7), 7.349$ (1H, d, J $7.20 \mathrm{~Hz}, \mathrm{H}-6), 7.159$ (2H, s, H-16 and H-20), 3.790 (6H, s, H-21), 3.637 (3H, s, H-22), 3.363 (2H, t, J $6.40 \mathrm{~Hz}, \mathrm{H}-12$ ), $2.736(2 \mathrm{H}, \mathrm{t}, J 6.00 \mathrm{~Hz}, \mathrm{H}-13) \mathrm{ppm} .{ }^{13} \mathrm{C}$ NMR: $\delta 173.90,172.38$ and 164.04 (C-10/C-11/C-14), 
153.61 (C-17 and C-19), 137.08-111.38 (10 C, aromatic and vinylic carbons), 98.26 (C-6 and C7) 61.00 (C-22), 56.60 (C-21), 29.62 (C-12 and C-13) ppm

$\mathrm{N}$-(Indole-3-carboxyl)-3',4',5'-trimethoxy-indole-3-carboxanilide (7e). To a magnetically stirred suspension of acid $11(0.21 \mathrm{~g}, 0.8 \mathrm{mmol})$, anilide $13(0.26 \mathrm{~g}, 0.8 \mathrm{mmol})$, anhydrous DIPEA $(0.42 \mathrm{~mL}, 2.4 \mathrm{mmol})$ and a catalytic quantity of DMAP in anhydrous $\mathrm{CHCl}_{3}(1.5 \mathrm{~mL})$ PyBrOP $(0.47 \mathrm{~g}, 1 \mathrm{mmol})$ was added. After $1 \mathrm{~h}$ at ambient temperature the resulting solution is diluted with more $\mathrm{CHCl}_{3}$ and washed once with a $5 \%$ aqueous $\mathrm{NaHCO}_{3}$ solution and twice with $\mathrm{H}_{2} \mathrm{O}$. Drying and evaporation left a residue from which $0.38 \mathrm{~g}$ ( $83 \%$ yield) of pure intermediate 20 was obtained as an oil following purification by FCC using as eluant the solvent system G. This compound had $\mathrm{R}_{\mathrm{f}}(\mathrm{G})$ 0.37. ESI-MS (m/z) : $592.43(\mathrm{MNa}), 570.50(\mathrm{MH})$. It was subsequently dissolved into a $50 \%$ solution $\left(8 \mathrm{ml}\right.$ ) of TFA in $\mathrm{CH}_{2} \mathrm{Cl}_{2}$ and kept at ambient temperature for $1 \mathrm{~h}$. Evaporation to dryness, trituration with $\mathrm{Et}_{2} \mathrm{O}$, overnight refrigeration and finally filtration gave $\mathbf{7 b}$ as its corresponding trifluoroacetate salt. This was then added to a 5\% aqueous $\mathrm{NaHCO}_{3}$ solution and extracted twice with EtOAc. The combined organic layers were washed twice with $\mathrm{H}_{2} \mathrm{O}$, dried and evaporated to give $0.24 \mathrm{~g}(77 \%$ yield) of pure $7 \mathbf{b}$. Bisamide 7b had m.p. 245-46 ${ }^{\circ} \mathrm{C}, \mathrm{R}_{\mathrm{f}}$ (F) 0.22. Anal. Calcd for $\mathrm{C}_{27} \mathrm{H}_{23} \mathrm{~N}_{3} \mathrm{O}_{5}$ (469.5): C, 69.07; H, 4.94; N, 8.95. Found: C, 68.88; H, 5.12; N, 9.08.

ESI-MS (m/z): $492.27(M N a), 470.14(M H) .{ }^{1} \mathrm{H}$ NMR (DMSO-d $): \delta 12.376(1 \mathrm{H}, \mathrm{br} . \mathrm{S}, \mathrm{H}-$ 20), 9.898 (1H, s, NH), 8.883 (1H, s, H-2), 8.333 (1H, d, J $8.00 \mathrm{~Hz}, \mathrm{H}-8), 8.323$ (1H, s, H-13), $8.228(1 \mathrm{H}, \mathrm{d}, J 8.00 \mathrm{~Hz}, \mathrm{H}-5), 8.073(1 \mathrm{H}, \mathrm{d}, J 7.60 \mathrm{~Hz}, \mathrm{H}-16), 7.593$ (1H, d, J $8.00 \mathrm{~Hz}, \mathrm{H}-19)$, $7.390(1 \mathrm{H}, \mathrm{t}, J 6.80 \mathrm{~Hz}, \mathrm{H}-7), 7.355$ (1H, t, J $6.40 \mathrm{~Hz}, \mathrm{H}-6), 7.313$ (1H, t, J 7.20 Hz, H-17), $7.390(1 \mathrm{H}, \mathrm{t}, J 6.80 \mathrm{~Hz}, \mathrm{H}-18), 7.157$ (2H, s, H-22 and H-26), $3.766(6 \mathrm{H}, \mathrm{s}, \mathrm{H}-27), 3.626(3 \mathrm{H}, \mathrm{s}$, H-28) ppm. ${ }^{13} \mathrm{C}$ NMR: $\delta 164.43$ (C-10), 163.02 (C-11), 153.55 (C-23 and C-25), 137.40-108.88 (18 C, aromatic and vinylic carbons), 98.51 (C-6 and C-7) 61.00 (C-28), 56.70 (C-27) ppm

Maleic acid monodiphenylmethyl ester (21). To an ice-cold, magnetically stirred, solution of diphenylmethanol (1.48 $\mathrm{g}, 8 \mathrm{mmol})$, anhydrous $\mathrm{Et}_{3} \mathrm{~N}(1.24 \mathrm{~mL}, 8.8 \mathrm{mmol})$ and a catalytic quantity of DMAP in anhydrous $\mathrm{CH}_{2} \mathrm{Cl}_{2}(24 \mathrm{~mL})$ maleic anhydride $(0.78 \mathrm{~g}, 8 \mathrm{mmol})$ was added and the reaction mixture was allowed to stand at that temperature for $30 \mathrm{~min}$ and then for overnight at ambient temperature. The resulting solution was diluted with more $\mathrm{CH}_{2} \mathrm{Cl}_{2}$, washed once with an ice-cold 5\% aqueous citric acid solution and twice with $\mathrm{H}_{2} \mathrm{O}$. Drying and evaporation left $1.68 \mathrm{~g}$ (74\% yield) of the product 21 as an oil. Acid 21 had $\mathrm{R}_{\mathrm{f}}(\mathrm{D})$ 0.31. Anal. Calcd for $\mathrm{C}_{17} \mathrm{H}_{14} \mathrm{O}_{4}$ (282.30): C, 72.33; H, 5.00. Found: C, 72.57; H, 4.86.

IR: 3200-2400 (CO-OH), 1727 (br., CO-O and CO-OH), $1646(\mathrm{C}=\mathrm{C}) \mathrm{cm}^{-1} .{ }^{1} \mathrm{H}$ NMR: $\delta 7.36-$ $7.30(10 \mathrm{H}, \mathrm{m}, \mathrm{Ph}-\mathrm{H}), 6.977\left(1 \mathrm{H}, \mathrm{s}, \mathrm{Ph}_{2} \mathrm{CH}\right), 6.446(2 \mathrm{H}, \mathrm{Abq}, J 12.40 \mathrm{~Hz}, \mathrm{CH}=\mathrm{CH}) \mathrm{ppm}$.

$\mathrm{N}$-(O-Diphenylmethylmaleyl)-3', 4',5'-trimethoxy-indole-3-carboxanilide (22). To a magnetically stirred solution of acid $22(0.28 \mathrm{~g}, 1 \mathrm{mmol})$, the anilide $13(0.30 \mathrm{~g}, 0.91 \mathrm{mmol})$ and DIPEA $(0.48 \mathrm{~mL}, 2.74 \mathrm{mmol})$ in anhydrous $\mathrm{CH}_{2} \mathrm{Cl}_{2}(4 \mathrm{~mL})$ PyBrOP $(0.61 \mathrm{~g}, 1.3 \mathrm{mmol})$ was added. The resulting solution was kept at ambient temperature for overnight and then diluted with more $\mathrm{CH}_{2} \mathrm{Cl}_{2}$. Washing once with a $5 \%$ aqueous $\mathrm{NaHCO}_{3}$ solution and twice with $\mathrm{H}_{2} \mathrm{O}$, followed by drying and evaporation gave a yellowish foam. FCC of crude product, using the solvent system E for elution, gave $0.30 \mathrm{~g}$ (56\% yield) of intermediate 22 as a white solid. Ester 22 had m.p. 195$97{ }^{\circ} \mathrm{C}, \mathrm{R}_{\mathrm{f}}$ (E) 0.5. Anal. Calcd for $\mathrm{C}_{35} \mathrm{H}_{30} \mathrm{~N}_{2} \mathrm{O}_{7}$ (590.64): C, 71.18; H, 5.12; N, 4.74. Found: C, $71.40 ; \mathrm{H}, 5.01 ; \mathrm{N}, 4.55$. 
IR: 3383 (NH-CO), 1719 (CO-O), 1687 (N-CO), $1656(\mathrm{NH}-\mathrm{CO}), 1623(\mathrm{C}=\mathrm{C}) \mathrm{cm}^{-1}$. ESI-MS $(\mathrm{m} / \mathrm{z}): 1203.28(2 M+\mathrm{Na}), 630.65(M \mathrm{~K}), 613.58(\mathrm{MNa}), 591.79(\mathrm{MH}) .{ }^{1} \mathrm{H}$ NMR $\left(\mathrm{DMSO}^{-} \mathrm{d}_{6}\right)$ : $9.992(1 \mathrm{H}, \mathrm{s}, \mathrm{NH}), 8.544(1 \mathrm{H}, \mathrm{s}, \mathrm{H}-2), 8.353(1 \mathrm{H}, \mathrm{br} . \mathrm{d}, J 7.20 \mathrm{~Hz}, \mathrm{H}-8), 8.297(1 \mathrm{H}, \mathrm{d}, J 7.60 \mathrm{~Hz}$, H-5), 7.469 (1H, d, J $12.00 \mathrm{~Hz}, \mathrm{H}-12), 7.417$ (2H, m, H-6 and H-7), 7.143 (10H, m, Ph-H), 7.109 $\left(2 \mathrm{H}, \mathrm{s}, \mathrm{H}-17\right.$ and H-21), $6.772(1 \mathrm{H}, \mathrm{s}, \mathrm{H}-15), 6.677(1 \mathrm{H}, \mathrm{d}, J 12.00 \mathrm{~Hz}, \mathrm{H}-13)$ ppm. ${ }^{13} \mathrm{C}$ NMR: : $\delta$ 166.32, 163.47 and 161.95 (C-10/C-11/C-14), 153.61 (C-18 and C-20), 140.14-116.14 (22 C, aromatic and vinylic carbons), 98.61 (C-6 and C-7), 78.224 (C-15), 60.61 (C-23), 56.70 (C-22) ppm

$\boldsymbol{N}$-Maleyl-3', 4',5'-trimethoxy-indole-3-carboxanilide (7b). A solution of ester 22 (0.28 g, 0.47 mmol) in $\mathrm{CH}_{2} \mathrm{Cl}_{2}(4.5 \mathrm{~mL})$ and TFA $(1.5 \mathrm{~mL})$ was prepared and allowed to stand at ambient temperature for $5 \mathrm{~min}$, whereby deprotection was found complete (TLC). Dilution with more $\mathrm{CH}_{2} \mathrm{Cl}_{2}$, followed by washing with $\mathrm{H}_{2} \mathrm{O}$ twice, drying and evaporation left an oily residue. Product $7 \mathrm{~b}$ was finally obtained pure $(0.12 \mathrm{~g}, 60 \%$ yield $)$ as a white solid through FCC using as eluant the solvent system H. Compound 7b had m.p. 108-09 ${ }^{\circ} \mathrm{C}, \mathrm{R}_{\mathrm{f}}(\mathrm{B})$ 0.24. Anal. Calcd for $\mathrm{C}_{22} \mathrm{H}_{20} \mathrm{~N}_{2} \mathrm{O}_{7}$ (424.41): C, 62.26; H, 4.75; N, 6.60. Found: C, 61.95; H, 4.83; N, 6.79.

IR: 3600-2800 (br., $\mathrm{NH}-\mathrm{CO}$ and CO-OH), 1642 (br., N-CO, NH-CO, CO-OH) cm ${ }^{-1} .{ }^{1} \mathrm{H}$ NMR $\left(\mathrm{DMSO}_{-} \mathrm{d}_{6}\right): \delta 11.911(1 \mathrm{H}, \mathrm{s}, \mathrm{OH}), 9.678(1 \mathrm{H}, \mathrm{s}, \mathrm{NH}), 8.304(1 \mathrm{H}, \mathrm{s}, \mathrm{H}-2), 8.183(1 \mathrm{H}, \mathrm{d}, J 7.60$ Hz, H-8), $7.453(1 \mathrm{H}, \mathrm{d}, J 8.00 \mathrm{~Hz}, \mathrm{H}-5), 7.217$ (2H, s, H-16 and H-20), 7.137 (2H, m, H-6 and H-7), $6.225(1 \mathrm{H}, \mathrm{d}, J 12.00 \mathrm{~Hz}, \mathrm{H}-12), 5.662(1 \mathrm{H}, \mathrm{d}, J 12.00 \mathrm{~Hz}, \mathrm{H}-13), 3.765(6 \mathrm{H}, \mathrm{s}, \mathrm{H}-21)$, $3.616(3 \mathrm{H}, \mathrm{s}, \mathrm{H}-22) \mathrm{ppm} .{ }^{13} \mathrm{C}$ NMR: $\delta 170.12,167.74$ and 164.09 (C-10/C-11/C-14), 153.83 (C17 and C-19), 137.12-111.34 (12 C, aromatic and vinylic carbons), 98.32 (C-6 and C-7) 62.57 (C-22), $56.62(\mathrm{C}-21) \mathrm{ppm}$

\section{References}

1. (a) Sporn, M. B.; Roberts, A. B.; Goodman, D. S., Eds.; The Retinoids: Biology, Chemistry and Medicine, 2nd Edn; Raven Press: New York, 1994. (b) Packer, L. Ed. Methods in Enzymology, Academic Press: New York, 1991, Vol. 90, Part B. (c) Packer, L. Ed.; Methods in Enzymology, Academic Press: New York, 1990, Vol. 89, Part A. (d) Dawson, M. I.; Okamura, W. H., Eds.; Chemistry and Biology of Synthetic Retinoids, CRC Press: Boca Baton, 1990. (e) Sporn, M. B.; Roberts, A. B.; Goodman, D. S., Eds.; The Retinoids, Vol. 1 and 2, Academic Press: Orlando, 1984. (f) Mayer, H.; Bollag, W.; Hänni, R.; Rüegg, R. Experientia 1978, 34, 1105.

2. Lippman, S. M; Lotan, R. J. Nutr. 2000, 130 (2S Suppl), 479S.

3. Papadimou, E.; Monastirli, A.; Tsambaos, D.; Merk, H. F.; Drainas, D. Skin Pharmacol. Appl. Skin Physiol. 2000, 13, 345. Papadimou, E.; Georgiou,S.; Tsambaos, D.; Drainas, D. J. Biol. Chem. 1998, 273, 24375.

4. An analogous restriction of the $\mathrm{C} 9-\mathrm{C} 10$ double bond in all-trans-retinoic acid within a cyclohexene ring has been recently reported. Katsuta, Y.; Aoyama, Y.; Osone, H.; Wada, A.; Ito, M. J. Chem. Soc., Perkin Trans. 1 1997, 1405.

5. (a) Han, G.; Lewis, A.; Hruby, V. J. Tetrahedron Lett. 2001, 42, 4601. (b) Franzén, H.; Grehn, L.; Ragnarsson, U. J. Chem. Soc., Chem. Commun. 1984, 1699. (c) Grehn, L.; Ragnarsson, U. Angew. Chem., Int. Ed. 1984, 23, 296. 
6. Barlos, K.; Papaioannou, D.; Theodoropoulos, D. J. Org. Chem. 1982, 47, 1324 and references cited therein.

7. Vassis, S.; Govaris, I.; Voyagi, K.; Mamos, P.; Papaioannou, D. Tetrahedron Lett. 2002, 43, 2597.

8. Barlos, K.; Gatos, D.; Kallitsis, J.; Papaphotiou, G.; Sotiriou, P.; Wenqing, Y.; Schäfer, W. Tetrahedron Lett. 1989, 30, 3943.

9. Militsopoulou, M.; Tsiakopoulos, N.; Chochos, C.; Magoulas, G.; Papaioannou, D. Tetrahedron Lett. 2002, 43, 2593.

10. Perrin, D. D.; Armarego, W. L. F.; Perrin, D. F. Purification of Laboratory Chemicals, 2nd Edn.; Pergamon: Oxford, 1980. 